\title{
Učinkovitost skidera Timberjack 240 C pri privlačenju drva u brdskim uvjetima primjenom sortimentne metode
}

\author{
Željko Zečić, Ivan Martinić, Dinko Vusić, Matija Bakarić, \\ Davorin Pečnjak, Matija Landekić
}

\begin{abstract}
Nacrtak - Abstract
U radu je istraživan učinak skidera Timberjack 240 C pri privlačenju dronih sortimenata $u$ dovršnoj i naplodnoj sječi. Terenska su istraživanja provedena na području Šumarije Okučani u odjelu 44 a gospodarske jedinice Okučanska brda i na području Šumarije Nova Gradiška u odjelu 74 a gospodarske jedinice Južni Psunj. Kod skidera Timberjack 240C u odjelu 44a tijekom 11 dana na radilištu je snimljeno 4406,12 minuta, što iznosi 400,56 minuta na dan odnosno 83,45\% propisanoga radnoga vremena od 480 minuta. Od ukupnoga snimljenoga vremena na efektivno vrijeme otpada 3300,02 minute ili 74,90\%, dok na opće vrijeme otpada 1106,10 minuta ili 25,10 \%. Kod skidera Timberjack 240C u odjelu 74a tijekom 9 dana na radilištu je snimljeno 2641,57 minuta, što iznosi 293,51 minutu na dan, odnosno 61,15\% propisanoga radnoga vremena od 480 minuta. Od ukupnoga snimljenoga vremena na efektivno vrijeme otpada 2157,20 minuta ili $81,66 \%$, dok na opće vrijeme otpada 484,37 minuta ili 18,34 \%. Dodatno vrijeme iznosi 16,09 \% i 20,37 \% efektivnoga vremena. Skider Timberjack 240C pripada skupini visoko učinkovitih strojeva na privlačenju drva, a posebno u oplodnim sječama primjenom poludeblovne i deblovne metode. Za primjenu takva skidera potrebno je prethodno izraditi elaborat radilišta sa svim utjecajnim čimbenicima te neprestano nadzirati tijek rada. Privlačenjem dronih sortimenata postižu se značajno manji učinci zbog prosječno manjega obujma tovara.
\end{abstract}

Ključne riječi: skider Timberjack 240 C, privlačenje dronih sortimenata, proizvodnost, troškovi

\section{Uvod - Introduction}

Područje pridobivanja drva obuhvaća ljudsku djelatnost koja seže daleko u prošlost, a bavi se svrhovitom uporabom svih šumskih resursa, obnovljivih i neobnovljivih, ovisno o stupnju razvoja društva.

Pridobivanjem drva stvaraju se uvjeti za ostvarenje postavljenoga cilja gospodarenja u gospodarskim šumama odnosno omogućuje se obnova sastojina koja opet stvara uvjete za sječu. Osiguranje potrajnosti ekosustava osnovni je cilj gospodarenja šumama.

U gospodarenju šumama u Hrvatskoj se provode raznovrsne sječe. Svaka je sječa različita i zatijeva ekološki prihvatljivu tehnologiju odnosno metodu i način rada.

Početkom 60-ih godina $u$ iskorištavanje šuma uvode se adaptirani velikoserijski poljoprivredni traktori. Ugrađuju se jednobubanjska i dvobubanjska vitla te se drvo i sortimenti skupljaju i privlače iz ranije nepovoljnih i nedostupnih dijelova šuma $\mathrm{u}$ nepristupačnim terenskim i stanišnim uvjetima rada pa se značajno mijenjaju metode izradbe stabala. Tako se, na primjer, klasični način izrade sortimenata u sječini sve uspješnije zamjenjuje izradom sortimenata na pomoćnim i glavnim stovarištima, odnosno na međustovarištima. Rezultati su takva rada veća iskorištenost kapaciteta šumskih strojeva, veća proizvodnost rada, ekonomičnost te naposljetku i humanizacija rada.

U radu se istražuje učinak skidera Timberjack 240 C (slika 1) pri privlačenju drvnih sortimenata u naplodnom i dovršnom sijeku na području Uprave šuma podružnice Nova Gradiška.

Uporaba suvremenih motornih pila i šumarske mehanizacije (poljoprivrednih traktora, traktora 
opremljenih vitlom, skidera, forvardera, harvestera i kamiona s hidrauličnom dizalicom) smanjila je broj djelatnika u pridobivanju drva i njihova naprezanja pri obavljanju radnih zadataka.

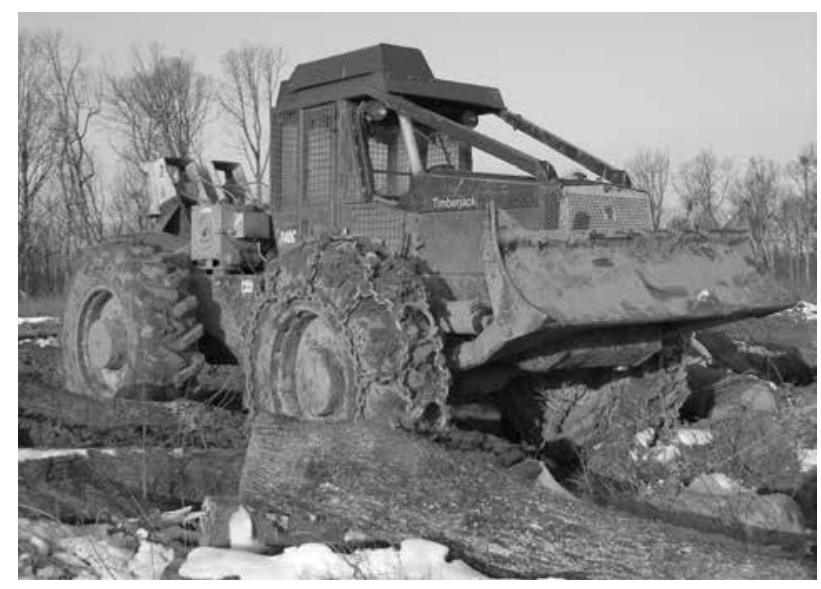

Slika 1. Skider Timberjack $240 \mathrm{C}$

Fig. 1 Skidder Timberjack 240 C

Krpan (1992) eksploataciju šuma dijeli na fazu sječe i izradbe te fazu transporta drva. Fazu transporta dijeli na skupljanje, privlačenje i daljinski transport te ih definira na sljedeći način. Skupljanje je pomicanje dijelova stabala ili cijelih stabala ljudskom, životinjskom ili mehaničkom snagom od panja do mjesta pripreme tovara. Pod privlačenjem on razumijeva pomicanje stabala ili dijelova stabala do pomoćnoga stovarišta. Daljinski transport odnosi se na pomicanje dijelova stabala ili stabala od pomoćnoga stovarišta do korisnika.

Uvođenjem mehanizacije nastoji se, prema Bojaninu (1971), povećati učinak, smanjiti broj radnika, svesti umor radnika na minimum te smanjiti troškove po jedinici proizvoda na najmanju mjeru.

Bojanin (1983) piše o proučavanju mehanizacije u eksploataciji šuma s dva aspekta: radno-tehnološkoga i ekonomskoga. Prema njemu tehničko rješenje ne mora uvijek biti i ekonomsko, najbolje. Pritom je bitno da se u određenim uvjetima s optimalnom tehnologijom za određeni stroj osigura najpovoljniji ekonomski trenutak. Međutim, teško je uvijek izabrati najpovoljniju tehnologiju i strojeve za šumarstvo s obzirom na široku lepezu ponude $s$ različitom nabavnom cijenom i tehničkim svojstvima.

Matić (1983) ističe da za svaki stroj treba napraviti analizu njegova djelovanja na šumski ekosustav pri čemu bi odlučujuću riječ trebao imati šumar koji dobro poznaje ekološke, biološke i šumskouzgojne probleme. Stroj treba prilagoditi zahtjevima šume, a ne šumu pokušavati prilagođavati stroju.
Krpan (1990), s aspekta iskorištavanja šuma, dijeli šumsku površinu Hrvatske na tri zone, i to na zonu nizinskih šuma, zonu brdskih šuma središnjega i rubnoga gorja Panonske nizine te zonu brdskih i gorskih šuma Dinarida. Razredbu i razvrstavanje šumskih terena s obzirom na iskorištavanje šuma nužno je provesti zbog dobivanja željenih informacija za primjenu određenih strojeva i tehnologije pridobivanja drva.

Bojanin i Krpan (1997) pišu da se tijekom razvoja jednodobnih sastojina mijenjaju radni uvjeti, što uvjetuje vremensku promjenu tehnologije i sredstava za rad $u$ iskorištavanju šuma. Također pišu da se kod prebornih šuma stabla sijeku iznad promjera sječive zrelosti, zbog čega se tijekom vremena ne mijenjaju tehnologija i sredstva za rad.

Sabo (2003) smatra da je potrebno izraditi radnu razredbu sastojina radi vrednovanja kakvoće obavljenih radova u iskorištavanju šuma. Tvrdi da, ako se ne obavi radna razredba, neće biti moguće unaprijediti sustav vrednovanja radova na pridobivanju drva, odnosno drugih radnih procesa u šumarstvu.

\section{Materijal i metode-Material and methods}

\subsection{Područje istraživanja - Research area}

Uprava šuma podružnica Nova Gradiška jedna je od 16 uprava šuma koje posluju u sklopu poduzeća Hrvatske šume d.o.o. U zemljopisnom pogledu zauzima područje srednjega posavskoga bazena sjeverno od rijeke Save i brdsko područje južnih ekspozicija od Lipovljana do istočne granice Brodsko-posavske županije te južne ekspozicije planine Psunj.

Šumarija Nova Gradiška smještena je u gradu Nova Gradiška. Prostire se na zapadu od ceste Ratkovac-Širinci, a istočno završava kod sela Gunjavci. Južna granica nalazi se na rijeci Savi, a sjeverna na najvišim vrhovima Psunja.

Površina Šumarije iznosi 13 327,11 ha. Drvna zaliha iznosi $2853941 \mathrm{~m}^{3}$, a prirast $93398 \mathrm{~m}^{3}$ godišnje. Ukupni desetogodišnji etat iznosi $544220 \mathrm{~m}^{3}$, od čega je etat glavnoga prihoda $304082 \mathrm{~m}^{3}$ i prethodnoga $240138 \mathrm{~m}^{3}$. Najrasprostranjenije su vrste obična bukva, hrast kitnjak i lužnjak.

Šumarija Okučani smještena je u naselju Okučani. Prostire se na istoku od ceste Ratkovac-Širinci, a zapadno završava kod sela Borovac. Južna granica nalazi se u naselju Okučani, a sjeverna kod sela Bijela Stijena i Gornji Rogolji.

Površina Šumarije iznosi 7236 ha. Drvna zaliha iznosi $1957970 \mathrm{~m}^{3}$, a prirast $82843 \mathrm{~m}^{3}$ godišnje. 
Ukupni desetogodišnji etat iznosi $480902 \mathrm{~m}^{3}$, od čega etat glavnoga prihoda $284107 \mathrm{~m}^{3}$ i prethodnoga $196795 \mathrm{~m}^{3}$.

Istraživanje je rađeno $u$ gospodarskim jedinicama Južni Psunj i Okučanska brda. GJ Južni Psunj sastoji se od 103 odjela, s prosječnom površinom od 63,99 ha. Površina gospodarske jedinice iznosi 6590,83 ha, od čega je 6410,72 ha obrasloga zemljišta, 31,08 ha neobrasloga proizvodnoga zemljišta, 96,76 ha neobrasloga neproizvodnoga zemljišta i 52,27 ha neplodnoga zemljišta. Drvna zaliha iznosi 1764160 $\mathrm{m}^{3}$, a prirast $37846 \mathrm{~m}^{3}$. Etat glavnoga prihoda iznosi $197116 \mathrm{~m}^{3}$, a etat prethodnoga prihoda $159719 \mathrm{~m}^{3}$. GJ Okučanska brda sastoji se od 64 odjela, s prosječnom površinom od 52,09 ha. Površina gospodarske jedinice iznosi 3333,99 ha, od čega je 3075,45 ha obrasloga zemljišta, 196,10 ha neobrasloga proizvodnoga zemljišta, 36,63 ha neobrasloga neproizvodnoga zemljišta i 25,81 ha neplodnoga zemljišta. Drvna zaliha iznosi $760263 \mathrm{~m}^{3}$, a prirast $21451 \mathrm{~m}^{3}$. Etat glavnoga prihoda iznosi $133933 \mathrm{~m}^{3}$, a etat prethodnoga prihoda $69814 \mathrm{~m}^{3}$.

\subsection{Metode istraživanja - Research methods}

Pri studiju se rada i vremena u pridobivanju drva podaci utroška vremena snimaju mehaničkim ili digitalnim kronometrom. U iskorištavanju se šuma primjenjuje najčešće povratna i protočna metoda kronometrije. Obje imaju prednosti i nedostatke. U praksi se zbog određenih prednosti primjenjuje povratna metoda. Taboršak (1987) preporučuje povratnu metodu te navodi njezine prednosti i nedostatke. Prednosti su izravno mjerenje trajanja pojedinih radnih sastavnica i prekida koji se izravno mjere i upisuju u opažački list bez naknadnih računanja. Odmah se vide nepravilnosti $u$ radu ili opravdani prekidi u radu. Ako se snimanje prekine iz bilo kojih razloga, može se nastaviti. Moguće je očitovanje veoma kratkih zahvata. Nedostaci su dugo uvježbavanje snimača, kronometar posebne konstrukcije, gubici zbog vraćanja kazaljke u početni položaj, velika koncentracija snimača. Barnes (1964) daje prednost povratnoj metodi pred protočnom zbog toga što se utrošeno vrijeme pojedinoga radnoga zahvata može odmah pročitati na opažačkom listu te snimatelj i analitičar mogu bolje uočiti razlike za svaki radni zahvat.

Iz navedenih je razloga za mjerenje vremena trajanja pojedinih radnih zahvata $u$ ovim istraživanjima primijenjena povratna metoda kronometrije.

Snimanje rada na terenu obavljali su šumarski inženjeri i pomoćni radnici koji su posebno pripremljeni za tu svrhu. Prije početka snimanja snima- telji su dobro upoznati s radilištem i tehnologijom rada kako bi na vrijeme uočili i snimili svaki ciklični i povremeni rad te da svaki prekid svrstaju u pripadajuću kategoriju. Koncentracija i uvježbanost snimatelja vrlo su važni pri prikupljanju podataka (Taboršak 1987). Za mjerenje utrošaka vremena povratnom metodom kronometrije nabavljena je oprema koju čine snimačka daska, kronometar, ručni sat, opažački listovi, mjerni lanac te pribor za pisanje. Kronometar za snimanje je tipa Heuer s podjelom na $1 / 100 \mathrm{~min}$ uz preciznost očitanja od $0,01 \mathrm{~min}$ prilagođen za rad povratnom metodom snimanja. Ručni se sat koristi samo za mjerenje kontrolnoga vremena. U svakom su turnusu utvrđene dimenzije trupaca u tovaru. Za mjerenje srednjega promjera obloga drva koristili smo se drvenom promjerkom $\mathrm{s}$ točnošću očitanja na jedan centimetar. Duljinu sortimenta mjerili smo mjernom letvom (špicmetrom) $\mathrm{s}$ točnošću mjerenja na jedan decimetar. Mjerenje udaljenosti vožnje praznoga i opterećenoga traktora po vlaci i pomoćnom stovarištu utvrdili smo pomoću desetmetarske obilježbe vlaka i procjene duljine imeđu točaka obilježbe. Udaljenosti vožnje opterećenoga i neopterećenoga traktora od mjesta formiranja tovara u sječini do vlaka i obratno izmjerene su mjernom vrpcom dužine 50 metara.

Snimljena su vremena obrađena prema raspodjeli vremena na efektivno i opće vrijeme. Efektivno vrijeme (cikličko, operativno vrijeme ili čisto vrijeme rada) javlja se u svakom ciklusu i troši za izvršenje radnoga naloga. Dio efektivnoga vremena obrađuje se kao fiksno, a dio vremena kao varijabilno vrijeme (Bojanin 1980). Fiksno se vrijeme odnosi na efektivno vrijeme utrošeno za rad $u$ sječini i na pomoćnom stovarištu i ne ovisi o udaljenosti privlačenja ili udaljenosti izvlačenja užeta ili privitlavanja. U varijabilno se vrijeme ubraja vožnja opterećenoga i neopterećenoga traktora. Opće vrijeme obuhvaća sve prekide, povremene radove i pripremno-završno vrijeme. Vrijeme prekida dijeli se na opravdane i neopravdane prekide.

\subsection{Organizacija radilišta - Organization of work site}

Organizacija radilišta obuhvaća sve bitne elemente koji izravno ili neizravno utječu na proizvodnju i izvršenje radnih zadataka. Planiranje radne snage i potrebne mehanizacije ubraja se u najvažnije sastavnice organizacije radilišta, a planira se na temelju potrebnih norma dana. Pozornost treba posvetiti zadanim rokovima za izvršenje zadaća jer njihovo neispunjavanje dovodi do upitnoga provođenja godišnjega plana proizvodnje. 
Priprema se rada prema Vili (1962) dijeli na tehničku, tehnološku i operativnu. Krivec ju (1973) dijeli na uredsku pripremu, terensku pripremu i pripremu radilišta.

Kvalitetna priprema rada stavlja pred nas ove ciljeve:

$\Rightarrow$ kvalitetno planiranje i provođenje propisa gospodarskih jedinica

$\Rightarrow$ najkvalitetnije zadovoljenje ciljeva u uzgoju, zaštiti i iskorištavanju šuma

$\Rightarrow$ obrazovanje kadrova

$\Rightarrow$ planiranje tehnologije i metode rada

$\Rightarrow$ planiranje kapaciteta

$\Rightarrow$ planiranje zaštite na radu

$\Rightarrow$ informatičku obradu podataka.

U pripremi radilišta razlikuje se uredska i terenska priprema rada. Uredska priprema obuhvaća proučavanje uređajnih podataka, izradu plana sječa (ŠP-1), pripremu karata i definiranje radilišta. Terenska se priprema sastoji od rekognosciranja terena, vođenja radne skice, ucrtavanja uzgojnih radova, obilježavanja radničkih sječnih linija, trasiranja traktorskih putova, kategorizacije terena za privlačenje i iznošenje drva, kategorizacije terena za izgradnju traktorskih putova, uređivanje pomoćnih stovarišta i doznaka stabala za sječu.

Nakon obavljene uredske i terenske pripreme rada izrađuje se elaborat radilišta koji sadrži ove sastavnice:

$\Rightarrow$ opis radilišta

$\Rightarrow$ ciljeve gospodarenja

$\Rightarrow$ uzgojne radove
$\Rightarrow$ sječu i izradu

$\Rightarrow$ privlačenje ili iznošenje

$\Rightarrow$ prijevoz

$\Rightarrow$ prometnice

$\Rightarrow$ zaštita na radu.

U istraživanim sječinama primijenjena je sortimentna metoda sječe i izradbe hrasta kitnjaka i bukve, a privlačenje se obavljalo zglobnim traktorom Timberjack $240 \mathrm{C}$ do pomoćnoga stovarišta.

\section{Rezultati i rasprava Results and discussion}

Stabla su se sjekla u jesenskom razdoblju mirovanja vegetacije na radilištu Južni Psunj. Sječa u odjelu 44a, radilište Okučanska brda, obavljala se zimi. U tablici 1 prikazana je struktura drvnoga obujma koji je privukao skider Timberjack $240 \mathrm{C}$ na radilištima Južni Psunj i Okučanska brda.

Na radilištu Okučanska brda snimanjem je obuhvaćen 131 turnus s 890 komada obloga drva, ukupnoga obujma $344,64 \mathrm{~m}^{3}$. Ukupna duljina komada iznosila je 3507,5 metara. Srednji je obujam tovara $2,63 \mathrm{~m}^{3}$, dok je najmanji $1,42 \mathrm{~m}^{3}$, a najveći $5,28 \mathrm{~m}^{3}$. Srednji je promjer komada $35,1 \mathrm{~cm}$, najmanji $14 \mathrm{~cm}$, a najveći $78 \mathrm{~cm}$, dok je srednji obujam posječenih komada $0,39 \mathrm{~m}^{3}$. Srednja je duljina komada 3,9 metara, najmanja 1,8 metara, a najveća 8,5 metara.

Na radilištu Južni Psunj snimanjem je obuhvaćeno 38 turnusa s 283 komada obloga drva, ukupnoga obujma $123,88 \mathrm{~m}^{3}$. Ukupna duljina komada iznosila je 3020,7 metara. Srednji je obujam tovara $3,26 \mathrm{~m}^{3}$, dok je najmanji $1,22 \mathrm{~m}^{3}$, a najveći $5,13 \mathrm{~m}^{3}$. Srednji je

Tablica 1. Struktura drva privučena skiderom Timberjack $240 \mathrm{C}$ na radilištima

Table 1 Timber extraction structure in sub-compartments

\begin{tabular}{|c|c|c|c|c|c|c|}
\hline Šumarija - Forest office & \multicolumn{3}{|c|}{ Okučani } & \multicolumn{3}{|c|}{ Nova Gradiška } \\
\hline Gospodarska jedinica - Management unit & \multicolumn{3}{|c|}{ Okučanska brda } & \multicolumn{3}{|c|}{ Južni Psunj } \\
\hline \multirow{2}{*}{ Odjel, odsjek - Subcompartment } & \multicolumn{3}{|c|}{$44 a$} & \multicolumn{3}{|c|}{$74 a$} \\
\hline & * & $\mathrm{x}$ & ** & * & $\mathrm{x}$ & ** \\
\hline Ukupno privučen drv.obujam, $\mathrm{m}^{3}$ - Total skided timber volume, $\mathrm{m}^{3}$ & & 344,64 & & & 123,88 & \\
\hline Ukupno privučen broj komada - Total skidded number of pieces & & 890 & & & 283 & \\
\hline Ukupna duljina komada, $m$ - Total length of pieces, $m$ & & 3507,5 & & & 3020,7 & \\
\hline Ukupan broj turnusa - Total number of cycles & & 131 & & & 38 & \\
\hline Srednij obujam tovara, $\mathrm{m}^{3}-$ Mean load volume, $\mathrm{m}^{3}$ & 1,42 & 2,63 & 5,28 & 1,22 & 3,26 & 5,13 \\
\hline Prosječni broj komada u tovaru - Average number of pieces in load & 3 & 6,79 & 10 & 2,0 & 7,4 & 10,0 \\
\hline Srednja duljina komada, $\mathrm{m}$ - Mean piece length, $m$ & 1,8 & 3,9 & 8,5 & 3,1 & 10,7 & 20,2 \\
\hline Srednji obujam komada, $\mathrm{m}^{3}$ - Mean piece volume, $m^{3}$ & 0,054 & 0,387 & 2,176 & 0,03 & 0,44 & 3,17 \\
\hline Srednji promjer komada, $\mathrm{cm}$ - Mean piece diameter, $\mathrm{cm}$ & 14 & 35,1 & 78 & 7 & 21 & 58 \\
\hline
\end{tabular}

${ }^{*}-{ }^{-{ }^{* *}}$ ( ${ }^{*}$ - najmanja vrijednost, $\mathrm{x}$ - ukupno sredina, ${ }^{* *}$ - najveća vrijednost) - ${ }^{*}$ Minimal value, x Total or mean value, ${ }^{* *}$ Maximal value 
promjer komada $21 \mathrm{~cm}$, najmanji $7 \mathrm{~cm}$, a najveći 58 $\mathrm{cm}$, dok je srednji obujam posječenih komada 0,44 $\mathrm{m}^{3}$. Srednja je duljina komada 10,7 metara, najmanja 3,1 metar, a najveća 20,2 metra.

U istraživanju učinkovitosti privlačenja drva deblovnom metodom skiderom Timberjack 240C Kr- pan i Zečić (2001) u dovršnom sijeku (sječna gustoća $95,93 \mathrm{~m}^{3} /$ ha; prosječni obujam posječenoga stabla $4,16 \mathrm{~m}^{3}$ ) i u pripremnom sijeku (sječna gustoća 54,04 $\mathrm{m}^{3} /$ ha; prosječni obujam posječenoga stabla $1,94 \mathrm{~m}^{3}$ ) utvrđuju srednji obujam tovara od $4,24 \mathrm{~m}^{3} \mathrm{u}$ dovršnom i $6,31 \mathrm{~m}^{3} \mathrm{u}$ pripremnom sijeku.

Tablica 2. Struktura ukupno utrošena vremena skidera Timberjack $240 \mathrm{C}$ s dvobubanjskim vitlom na radilištima Okučanska brda i Južni Psunj

Table 2 Time structure of skidder Timberjack $240 \mathrm{C}$ in sub-subcompartments »Okučanska brda« and »Južni Psunj«

\begin{tabular}{|c|c|c|c|c|c|c|}
\hline \multirow{5}{*}{ Vrsta aktivnosti - Type of activity } & \multicolumn{3}{|c|}{ Okučanska brda, 44a } & \multicolumn{3}{|c|}{ Južni Psunj, 74a } \\
\hline & \multicolumn{3}{|c|}{ Utrošak vremena - Time consumption } & \multicolumn{3}{|c|}{ Utrošak vremena - Time consumption } \\
\hline & \multirow{2}{*}{$\begin{array}{l}\text { Ukupno } \\
\text { Total }\end{array}$} & \multicolumn{2}{|c|}{$\begin{array}{l}\text { Postotni udio prema } \\
\text { Percentage of }\end{array}$} & \multirow{2}{*}{$\begin{array}{c}\text { Ukupno } \\
\text { Total }\end{array}$} & \multicolumn{2}{|c|}{$\begin{array}{l}\text { Postotni udio prema } \\
\text { Percentage of }\end{array}$} \\
\hline & & $\begin{array}{l}\text { ukupnom } \\
\text { vremenu } \\
\text { total time }\end{array}$ & $\begin{array}{l}\text { efektivnom } \\
\text { vremenu } \\
\text { effective time }\end{array}$ & & $\begin{array}{l}\text { ukupnom } \\
\text { vremenu } \\
\text { total time }\end{array}$ & $\begin{array}{l}\text { efektivnom } \\
\text { vremenu } \\
\text { effective time }\end{array}$ \\
\hline & $\min$ & \multicolumn{2}{|c|}{$\%$} & $\min$ & \multicolumn{2}{|c|}{$\%$} \\
\hline 1. Vožnja neopterećenoga skidera - Travel time unloaded & 407,29 & 9,24 & 12,34 & 633,28 & 23,97 & 29,36 \\
\hline 2. Rad opterećenoga skidera - Loaded work & 553,41 & 12,56 & 16,77 & 685,08 & 25,93 & 31,76 \\
\hline 2.1 Vožnja opterećenoga skidera - Loaded driving & 533,82 & 12,12 & 16,18 & 676,16 & 25,60 & 31,34 \\
\hline 2.2 Privitlavanje na traktorskom putu - Winching on skid trail & 19,59 & 0,44 & 0,59 & 8,92 & 0,34 & 0,41 \\
\hline 3. Rad na sječini - Work at felling site & 1601,63 & 36,35 & 48,53 & 526,47 & 19,93 & 24,41 \\
\hline 3.1 Zauzimanje položaja - Taking a position & 126,45 & 2,87 & 3,83 & 37,77 & 1,43 & 1,75 \\
\hline 3.2 Izvlačenje užeta - Pulling the choker & 175,26 & 3,98 & 5,31 & 103,42 & 3,92 & 4,79 \\
\hline 3.2.1 Desni bubanj - Right drum & 87,50 & 1,99 & 2,65 & 47,80 & 1,81 & 2,22 \\
\hline 3.2.2 Lijevi bubanj - Left drum & 87,76 & 1,99 & 2,66 & 55,62 & 2,11 & 2,58 \\
\hline 3.3 Vezanje tovara - Choker setting & 1027,24 & 23,31 & 31,13 & 206,95 & 7,83 & 9,59 \\
\hline 3.3.1 Desni bubanj - Right drum & 498,53 & 11,31 & 15,11 & 104,34 & 3,95 & 4,84 \\
\hline 3.3.2 Lijevi bubanj - Left drum & 528,71 & 12,00 & 16,02 & 102,61 & 3,88 & 4,76 \\
\hline 3.4 Privitlavanje - Winching & 161,13 & 3,66 & 4,88 & 122,28 & 4,63 & 5,67 \\
\hline 3.4.1 Desni bubanj - Right drum & 81,66 & 1,85 & 2,47 & 56,91 & 2,15 & 2,64 \\
\hline 3.4.2 Lijevi bubanj - Left drum & 79,47 & 1,80 & 2,41 & 65,37 & 2,47 & 3,03 \\
\hline 3.5 Ispravljanje tovara - Correction of load & 30,91 & 0,70 & 0,94 & 54,84 & 2,08 & 2,54 \\
\hline 3.6 Silaženje i penjanje - Moving uphill and downhill & 80,64 & 1,83 & 2,44 & 1,21 & 0,05 & 0,06 \\
\hline 4. Rad na pomoćnom stovarištu - Work at landing & 737,69 & 16,74 & 22,35 & 312,37 & 11,83 & 14,48 \\
\hline 4.1 Vožnja opterećenoga skidera - Loaded travel & 79,70 & 1,81 & 2,42 & 60,16 & 2,28 & 2,79 \\
\hline $\begin{array}{l}\text { 4.2 Privitlavanje i premještanje skidera - Winching and } \\
\text { tractor repositioning }\end{array}$ & 17,83 & 0,40 & 0,54 & 3,18 & 0,12 & 0,15 \\
\hline 4.3 Silaženje i penjanje - Moving up and down & 72,02 & 1,63 & 2,18 & 0,36 & 0,01 & 0,02 \\
\hline 4.4 Odvezivanje tovara - Unhooking the load & 248,72 & 5,64 & 7,54 & 95,70 & 3,62 & 4,44 \\
\hline 4.5 Izvlačenje užeta ispod tovara - Pulling the choker under the load & 32,82 & 0,74 & 0,99 & 0,40 & 0,02 & 0,02 \\
\hline 4.6 Uređenje složaja - Arrangement of compound & 162,23 & 3,68 & 4,92 & 88,09 & 3,33 & 4,08 \\
\hline 4.7 Okretanje neopterećenoga skidera - Turning unloaded skidder & 52,75 & 1,20 & 1,60 & 21,98 & 0,83 & 1,02 \\
\hline 4.8 Vožnja neopterećenoga skidera - Unloaded travel & 71,62 & 1,63 & 2,17 & 42,50 & 1,61 & 1,97 \\
\hline 5. Efektivno vrijeme - Effective time & 3300,02 & 74,90 & 100,00 & 2157,20 & 81,66 & 100,00 \\
\hline 6. Opća vremena - General time & 1106,10 & 25,10 & & 484,37 & 18,34 & \\
\hline 7. Ukupno vrijeme - Total time & 4406,12 & 100,00 & & 2641,57 & 100,00 & \\
\hline 8. Ukupno privučeni drvni obujam, $\mathrm{m}^{3}$ - Total skidded timber volume, $\mathrm{m}^{3}$ & 344,64 & & & 123,88 & & \\
\hline 9. Efektivno vrijeme po jedinici, $\mathrm{min} / \mathrm{m}^{3}$ - Effective time, $\min / \mathrm{m}^{3}$ & 9,58 & & & 17,41 & & \\
\hline 10. Ukupno vrijeme po jedinici, $\mathrm{min} / \mathrm{m}^{3}$ - Total time, $\mathrm{min} / \mathrm{m}^{3}$ & 12,78 & & & 21,32 & & \\
\hline 11. Ostvareni dnevni učinak, $\mathrm{m}^{3} / \mathrm{dan}$ - Total daily output, $\mathrm{m}^{3} /$ day & 31,33 & & & 13,76 & & \\
\hline
\end{tabular}


U tablici 2 prikazano je ukupno utrošeno vrijeme skidera Timberjack 240 C, na dva odvojena radilišta, s relativnim udjelom pojedinoga vremena prema efektivnomu i ukupnomu vremenu.

Snimanje rada skidera na radilišu Okučanska brda trajalo je 11 radnih dana i snimljen je 131 turnus te je ostvaren dnevni učinak od $31,33 \mathrm{~m}^{3} /$ dan pri prosječnoj udaljenosti od $254 \mathrm{~m}$. Ukupno je snimano 4406,12 minuta rada. U tablici 2 prikazano je efektivno vrijeme u odnosu na ukupno vrijeme koje iznosi $74,90 \%$. Opće vrijeme iznosi $25,10 \%$ ukupnoga vremena. Zečić i dr. (2004) pri istraživanju privlačenja deblovnom metodom u dovršnom sijeku mješovite bukove sastojine utvrđuju srednji obujam tovara od $4,24 \mathrm{~m}^{3}$. U prebornoj sječi isti skider postiže u sortimentnoj metodi srednji obujam tovara od 4,63 $\mathrm{m}^{3}$ (Zečić i dr. 2010), a u čistoj sječi euroameričke topole deblovnom metodom postiže srednji obujam tovara od čak 8,63 m³ (Zečić i dr. 2011).

Vrijeme kretanja neopterećenoga skidera iznosi 407,29 minuta ili $12,34 \%$ efektivnoga vremena, odnosno 9,24\% ukupnoga vremena za prosječno ostvarenu udaljenost od $259 \mathrm{~m}$. Rad opterećenoga skidera iznosi 553,41 minutu, od čega na vožnju opterećenoga skidera otpada 533,82 minute ili 92,74\%, a na privitlavanje pri vuči na traktorskom putu 19,59 minuta ili 7,12 \% ukupnoga vremena rada opterećenoga traktora.

Zauzimanje položaja u sječini oduzima 126,45 minuta, odnosno 2,87 \% ukupnoga vremena ili 3,83 $\%$ efektivnoga vremena. Izvlačenje užeta iznosi 175,26 minuta, od čega na desni bubanj otpada 87,50 minuta ili $1,99 \%$, a na lijevi bubanj 87,76 minuta ili $1,99 \%$ ukupnoga vremena izvlačenja užeta. Vezanje tovara u sječini oduzima 1027,24 minute odnosno 23,31\% ukupnoga i 31,13\% efektivnoga vremena. Vidimo da vezanje tovara za lijevi bubanj iznosi 528,71 minutu, što je 12,00 \% ukupnoga vremena i 16,02 \% efektivnoga vremena, dok vezanje tovara za desni bubanj iznosi 498,53 minute ili 11,31 \% ukupnoga vremena, odnosno 15,11 \% efektivnoga vremena. Vrijeme je privitlavanja desnoga bubnja 81,66 minuta, što je 1,85\% ukupnoga vremena i 2,47\% efektivnoga vremena, dok je vrijeme privitlavanja lijevoga bubnja 79,47 minuta odnosno 1,80\% ukupnoga vremena ili $2,41 \%$ efektivnoga vremena. Ispravljanje tovara iznosi 30,91 minutu ili 0,70\% ukupnoga vremena i 0,94 \% efektivnoga vremena. Silaženje i penjanje traje 80,64 minute, što iznosi $1,83 \%$ ukupnoga vremena i $2,44 \%$ efektivnoga vremena. Rad na pomoćnom stovarištu iznosi 737,69 minuta ili 16,74 \% ukupnoga vremena i 22,35\% efektivnoga vremena. Pomoćno se stovarište protezalo i preko 100 metara (maksimalna udaljenost do 300 m). Vožnja opterećenoga traktora trajala je 79,70 minuta, što je 1,81 \% ukupnoga vremena i 2,42\% efektivnoga vremena za prosječnu udaljenost od $46 \mathrm{~m}$. Premještanje traktora i privitlavanje trajalo je 17,83 minute, što iznosi 0,40 $\%$ ukupnoga vremena ili $0,54 \%$ efektivnoga vremena. Silaženje i penjanje traktorista sa skidera bilo je minimalno i iznosilo je 72,02 minute, odnosno 1,63 $\%$ ukupnoga vremena i 2,18 \% efektivnoga vremena. Odvezivanje tovara i izvlačenje užeta ispod tovara radio je radnik preuzimač na pomoćnom stovarištu. Trajanje odvezivanja tovara iznosilo je 248,72 minute, odnosno 5,64 \% ukupnoga vremena ili 7,54 \% efektivnoga vremena. Izvlačenje užeta ispod tovara bilo je minimalno i iznosilo je 32,82 minute, odnosno 0,74 $\%$ ukupnoga vremena i $0,99 \%$ efektivnoga vremena. S obzirom na to da je pomoćno stovarište bilo dugačko do $300 \mathrm{~m}$, uređenje složaja iznosi 162,23 minute ili 3,68 \% ukupnoga vremena i 4,92\% efektivnoga vremena. Okretanje neopterećenoga skidera bilo je 52,75 minuta, odnosno 1,20 \% ukupnoga vremena i $1,60 \%$ efektivnoga vremena. Vožnja neopterećenoga skidera iznosi 71,62 minute, što je 1,63\% ukupnoga vremena, odnosno 2,17\% efektivnoga vremena za prosječnu udaljenost od $39 \mathrm{~m}$.

Snimanje rada skidera na radilišu Južni Psunj trajalo je 9 radnih dana i snimljeno je 38 turnusa te je ostvaren dnevni učinak od $13,76 \mathrm{~m}^{3} /$ dan. Ukupno je snimljeno 2641,57 minuta rada. U tablici 2 prikazano je efektivno vrijeme $\mathrm{u}$ odnosu na ukupno vrijeme koje iznosi $81,66 \%$. Opće vrijeme iznosi $18,34 \%$ ukupnoga vremena. Efektivno vrijeme po jedinici iznosi $17,41 \mathrm{~min} / \mathrm{m}^{3}$, a ukupno vrijeme $21,32 \mathrm{~min} / \mathrm{m}^{3}$.

Vrijeme kretanja neopterećenoga skidera iznosi 633,28 minuta ili $29,36 \%$ efektivnoga vremena, odnosno $23,97 \%$ ukupnoga vremena za prosječnu udaljenost od $1040 \mathrm{~m}$. Rad opterećenoga skidera iznosi 685,08 minuta, od čega na vožnju opterećenoga skidera otpada 676,16 minuta ili $25,60 \%$, a na privitlavanje pri vuči na traktorskom putu 8,92 minute ili $0,34 \%$ ukupnoga vremena rada opterećenoga skidera za prosječnu udaljenost od $1089 \mathrm{~m}$.

Zauzimanje položaja u sječini oduzima 37,77 minuta, odnosno 1,43\% ukupnoga vremena ili 1,75\% efektivnoga vremena. Izvlačenje užeta iznosi 103,42 minute, od čega na desni bubanj otpada 47,80 minuta ili $1,81 \%$, a na lijevi bubanj 55,62 minute ili $2,11 \%$ ukupnoga vremena izvlačenja užeta. Vezanje tovara u sječini oduzima 206,95 minuta, odnosno 7,83\% ukupnoga vremena od svih radova u sječini. Vidimo da vezanje tovara za lijevi bubanj iznosi 102,61 minutu, što je 3,88 \% ukupnoga vremena i 4,76\% 
efektivnoga vremena, dok vezanje tovara za desni bubanj iznosi 104,34 minute ili 3,95\% ukupnoga vremena, odnosno $4,84 \%$ efektivnoga vremena. Vrijeme je privitlavanja desnoga bubnja $56,91 \mathrm{mi}-$ nutu, što je 2,15\% ukupnoga vremena i 2,64\% efektivnoga vremena, dok je vrijeme privitlavanja lijevoga 65,37 minuta, odnosno 2,47 \% ukupnoga vremena ili 3,03\% efektivnoga vremena. Ispravljanje tovara iznosi 54,84 minute ili 2,08\% ukupnoga vremena i 2,54 \% efektivnoga vremena. Silaženje i penjanje iznosi 1,21 minutu, što je $0,05 \%$ ukupnoga vremena i $0,06 \%$ efektivnoga vremena. Rad na pomoćnom stovarištu iznosi 312,37 minuta ili $11,83 \%$ ukupnoga vremena i $14,48 \%$ efektivnoga vremena. Pomoćno se stovarište protezalo i preko 100 metara (maksimalna udaljenost 300 m). Vožnja opterećenoga skidera trajala je 60,16 minuta, što je 2,28 \% ukupnoga vremena i 2,79\% efektivnoga vremena pri srednjoj udaljenosti od $139 \mathrm{~m}$. Premještanje skidera i privitlavanje trajalo je 3,18 minuta, što iznosi $0,12 \%$ ukupnoga vremena ili $0,15 \%$ efektivnoga vremena. Silaženje i penjanje traktorista sa skidera bilo je minimalno i iznosilo je 0,36 minuta, odnosno $0,01 \%$ ukupnoga vremena i $0,02 \%$ efektivnoga vremena. Odvezivanje tovara i izvlačenje užeta ispod tovara radio je sâm traktorist ili pomoćni radnik na pomoćnom stovarištu. Trajanje odvezivanja tovara iznosilo je 95,70 minuta, odnosno 3,62 \% ukupnoga vremena ili 4,44\% efektivnoga vremena. Izvlačenje užeta ispod tovara bilo je minimalno i iznosi 0,40 minuta, odnosno $0,02 \%$ ukupnoga vremena i 0,02 $\%$ efektivnoga vremena. $\mathrm{S}$ obzirom na to da se pomoćno stovarište protezalo do 300 metara, uređenje složaja iznosi 88,09 minuta ili 3,33\% ukupnoga vremena i 4,08\% efektivnoga vremena. Okretanje neopterećenoga traktora trajalo je 21,98 minuta, odnosno $0,83 \%$ ukupnoga vremena i 1,02 \% efektivnoga vremena. Vožnja neopterećenoga skidera iznosi 42,50 minuta, što je 1,61 \% ukupnoga vremena, odnosno $1,97 \%$ efektivnoga vremena.

Struktura je općega vremena rada skidera Timberjack 240C na ta dva odvojena radilišta prikazana u tablici 3.

Opće vrijeme na radilištu Okučanska brda iznosi 1106,10 minuta ili $25,10 \%$ ukupnoga vremena. Na pripremno-završno vrijeme otpada 232,90 minuta, odnosno 21,06 \% općega vremena. Pripremno vrijeme čini vrijeme utrošeno za nalijevanje goriva, pokretanje traktora, zagrijavanje i rad u mjestu, ozračivanje hidraulike i kontrolu ulja. U završno vrijeme skidera ubraja se vrijeme utrošeno za parkiranje skidera, dnevni pregled sklopova skidera i vitla na kraju radnoga dana, zaključavanje skidera, pospre- manje stvari u kombi i čekanje radnika sjekača za odlazak s radilišta.

Tablica 3. Struktura općega vremena skidera Timberjack $240 \mathrm{C}$ Table 3 Time structure of skidder Timberjack 240 C

\begin{tabular}{|c|c|c|c|c|}
\hline \multirow{3}{*}{$\begin{array}{c}\text { Vrsta prekida } \\
\text { Kind of interruption }\end{array}$} & \multirow{2}{*}{\multicolumn{2}{|c|}{$\begin{array}{c}\text { Okučanska brda, } \\
44 a\end{array}$}} & \multirow{2}{*}{\multicolumn{2}{|c|}{$\begin{array}{l}\text { Južni Psunj, 74a } \\
\text { Utrošak vremena } \\
\text { Time consumption }\end{array}$}} \\
\hline & & & & \\
\hline & $\min$ & $\%$ & $\min$ & $\%$ \\
\hline $\begin{array}{l}\text { Pripremno-završno vrijeme } \\
\text { Preparatory final time }\end{array}$ & 232,90 & 21,06 & 9,15 & 1,89 \\
\hline Prekid za objed - Lunch break & 310,74 & 28,09 & 210,00 & 43,36 \\
\hline $\begin{array}{l}\text { Odmori i predasi } \\
\text { Rests and breaks }\end{array}$ & 72,65 & 6,57 & 42,81 & 8,84 \\
\hline $\begin{array}{l}\text { Ostali opravdani prekidi } \\
\text { Other justified breaks }\end{array}$ & 415,57 & 37,57 & 216,45 & 44,69 \\
\hline $\begin{array}{l}\text { Neopravdani prekidi } \\
\text { Unjustified breaks }\end{array}$ & 74,24 & 6,71 & 5,96 & 1,23 \\
\hline $\begin{array}{l}\text { Opće vrijeme - ukupno } \\
\text { General time in total }\end{array}$ & 1106,10 & 100,00 & 484,37 & 100,00 \\
\hline
\end{tabular}

Opće vrijeme na radilištu Južni Psunj iznosi 484,37 minuta ili 18,34\% ukupnoga vremena. Na pripremno-završno vrijeme otpada 9,15 minuta, odnosno 1,89\% općega vremena, što nije značajna količina dnevnoga radnoga vremena. Pripremno vrijeme čini vrijeme utrošeno za nalijevanje goriva, pokretanje skidera, zagrijavanje i rad u mjestu, ozračivanje hidraulike i kontrolu ulja. U završno vrijeme skidera ubraja se vrijeme utrošeno za parkiranje skidera na kraju radnoga dana, zaključavanje skidera, pospremanje stvari u kombi i čekanje radnika sjekača za odlazak s radilišta.

U tablici 4 prikazana je struktura dodatnoga vremena skidera Timberjack 240C na radilištima Okučanska brda i Južni Psunj. Na radilištu Okučanska brda dodatno vrijeme iznosi 530,89 minuta ili 16,09 \% efektivnoga vremena. Prekid za jelo traje 243,63 minute, odnosno $45,89 \%$ dodatnoga vremena. Odmor iznosi 65,82 minute ili $12,40 \%$ efektivnoga vremena. Ostali opravdani prekidi iznose 42,46 minuta ili 8,00\% dodatnoga vremena. Pripremno-završno vrijeme iznosi 178,98 minuta, što je 33,71 \% dodatnoga vremena.

Na radilištu Južni Psunj dodatno vrijeme iznosi 439,47 minuta ili 20,37 \% efektivnoga vremena. Prekid za jelo traje 165,10 minuta, odnosno 37,57 \% dodatnoga vremena. Odmor iznosi 42,81 minutu ili $9,74 \%$ efektivnoga vremena. Ostali opravdani prekidi iznose 216,45 minuta ili 49,25\% dodatnoga vremena. Najmanji iznos vremena ima pripremno-završno vrijeme i iznosi 9,15 minuta, što je 2,08 $\%$ dodatnoga vremena. 
Tablica 4. Dodatno vrijeme traktora Timberjack $240 \mathrm{C}$ Table 4 Allowance time of skidder Timberjack $240 \mathrm{C}$

\begin{tabular}{|l|c|c|c|c|}
\hline \multirow{2}{*}{ VP } & \multicolumn{2}{|c|}{ Okučanska brda 44a } & \multicolumn{2}{c|}{ Južni Psunj, 74a } \\
\cline { 2 - 5 } & \multicolumn{2}{|c|}{ UV } & \multicolumn{2}{c|}{ UV } \\
\cline { 2 - 5 } & $\min$ & $\%$ & $\min$ & $\%$ \\
\hline PZV & 178,98 & 33,71 & 9,15 & 2,08 \\
\hline Po & 243,63 & 45,89 & 165,10 & 37,57 \\
\hline op & 65,82 & 12,40 & 42,81 & 9,74 \\
\hline OOP & 42,46 & 8,00 & 216,45 & 49,25 \\
\hline DVu & 530,89 & 100,00 & 439,47 & 100,00 \\
\hline \multicolumn{5}{|c|}{} \\
\hline EV & 3300,02 & 2157,20 & \\
\hline DV & 530,89 & 16,09 & 439,47 & 20,37 \\
\hline FDV & 1,16 & & 1,20 & \\
\hline
\end{tabular}

VP - Vrsta prekida - Kind of break

UV - Utrošak vremena - Time consumption

PZV - Pripremno-završno vrijeme - Preparatory final time

Po - Prekid za objed - Lunch break

op - Odmori i predasi - Rests and breaks

OOP - Ostali opravdani prekidi - Other justified breaks

DVu - Dodatno vrijeme ukupno - Total allowance time

EV - Efektivno vrijeme - Effective time

DV - Dodatno vrijeme - Allowance time

FDV - Faktor dodatnoga vremena - Additional time factor
Za skider Ecotrac $120 \mathrm{~V}$ u brdskim uvjetima središnje Hrvatske, prema Horvatu i dr. (2007), faktor dodatnoga vremena iznosi 1,34, a u gorskim uvjetima prebornih šuma 1,18. Na osnovi tih podataka zaključuje se da dodatno vrijeme ne ovisi toliko o sastojinskim i eksploatacijskim čimbenicima koliko o organizaciji i nadzoru izvođenja radova pri privlačenju drva.

Norma vremena i dnevni učinak skidera Timberjack $240 \mathrm{C}$ s dvobubanjskim vitlom Adler HY 16 na radilištu Okučanska brda pri privlačenju drva primjenom sortimentne metode prikazani su u tablici 5. Neopterećeni skider za kretanje po vlaci i sječini trošio je od 1,22 minute na 100 metara do 11,70 minuta na 1000 metara, dok je opterećeni skider za istu udaljenosti trošio 1,79 minuta, odnosno 15,54 minute. Kretanje po pomoćnom stovarištu uzeto je za 100 metara te je iznosilo 1,08 minuta za neopterećeni skider i 1,47 minuta za opterećeni skider. Zbroj fiksnoga vremena iznosi 16,71 minutu. Efektivno se vrijeme kreće od 22,27 minuta za udaljenost od 100 metara do 46,51 minutu za udaljenost privlačenja od 1000 metara. Dodatno se vrijeme

Tablica 5. Norma vremena i dnevni učinak skidera Timberjack $240 \mathrm{C}$ pri privlačenju drvnih sortimenata na radilištu Okučanska brda Table 5 Norm of time and daily output of skidder Timberjack $240 \mathrm{C}$ in timber extraction in management unit Okučanska brda

\begin{tabular}{|c|c|c|c|c|c|c|c|c|c|c|c|c|c|}
\hline \multirow{2}{*}{$\begin{array}{l}\text { Udaljenost } \\
\text { Distance }\end{array}$} & \multicolumn{2}{|c|}{ VS } & \multicolumn{2}{|c|}{ PS } & \multirow{2}{*}{ SVv } & \multirow{2}{*}{ RS } & \multirow{2}{*}{ RPS } & \multirow{2}{*}{ SUI } & \multirow{2}{*}{ EV } & \multirow{2}{*}{$\begin{array}{c}\text { DV } \\
32,81 \%\end{array}$} & \multirow{2}{*}{ UVt } & \multirow{2}{*}{ NV } & \multirow{2}{*}{ DU } \\
\hline & NT & OT & NT & OT & & & & & & & & & \\
\hline $\mathrm{m}$ & & & & & & $\min$ & & & & & & $\mathrm{min} / \mathrm{m}^{3}$ & $\mathrm{~m}^{3} / \mathrm{dan}$ \\
\hline 100 & 1,22 & 1,79 & 1,08 & 1,47 & 5,56 & 12,23 & 4,48 & 16,71 & 22,27 & 3,58 & 25,86 & 9,83 & 48,83 \\
\hline 150 & 1,82 & 2,58 & 1,08 & 1,47 & 6,95 & 12,23 & 4,48 & 16,71 & 23,66 & 3,81 & 27,47 & 10,44 & 45,96 \\
\hline 200 & 2,41 & 3,37 & 1,08 & 1,47 & 8,33 & 12,23 & 4,48 & 16,71 & 25,04 & 4,03 & 29,07 & 11,05 & 43,43 \\
\hline 250 & 3,00 & 4,15 & 1,08 & 1,47 & 9,70 & 12,23 & 4,48 & 16,71 & 26,41 & 4,25 & 30,66 & 11,66 & 41,18 \\
\hline 300 & 3,59 & 4,92 & 1,08 & 1,47 & 11,06 & 12,23 & 4,48 & 16,71 & 27,77 & 4,47 & 32,24 & 12,26 & 39,15 \\
\hline 350 & 4,18 & 5,69 & 1,08 & 1,47 & 12,42 & 12,23 & 4,48 & 16,71 & 29,13 & 4,69 & 33,82 & 12,86 & 37,33 \\
\hline 400 & 4,76 & 6,46 & 1,08 & 1,47 & 13,78 & 12,23 & 4,48 & 16,71 & 30,49 & 4,91 & 35,39 & 13,46 & 35,67 \\
\hline 450 & 5,35 & 7,23 & 1,08 & 1,47 & 15,13 & 12,23 & 4,48 & 16,71 & 31,84 & 5,12 & 36,96 & 14,05 & 34,16 \\
\hline 500 & 5,93 & 7,99 & 1,08 & 1,47 & 16,47 & 12,23 & 4,48 & 16,71 & 33,18 & 5,34 & 38,52 & 14,65 & 32,77 \\
\hline 550 & 6,51 & 8,76 & 1,08 & 1,47 & 17,82 & 12,23 & 4,48 & 16,71 & 34,53 & 5,56 & 40,08 & 15,24 & 31,50 \\
\hline 600 & 7,09 & 9,52 & 1,08 & 1,47 & 19,16 & 12,23 & 4,48 & 16,71 & 35,87 & 5,77 & 41,64 & 15,83 & 30,32 \\
\hline 650 & 7,67 & 10,27 & 1,08 & 1,47 & 20,49 & 12,23 & 4,48 & 16,71 & 37,20 & 5,99 & 43,19 & 16,42 & 29,23 \\
\hline 700 & 8,25 & 11,03 & 1,08 & 1,47 & 21,83 & 12,23 & 4,48 & 16,71 & 38,54 & 6,20 & 44,74 & 17,01 & 28,22 \\
\hline 750 & 8,83 & 11,79 & 1,08 & 1,47 & 23,16 & 12,23 & 4,48 & 16,71 & 39,87 & 6,42 & 46,29 & 17,60 & 27,27 \\
\hline 800 & 9,40 & 12,54 & 1,08 & 1,47 & 24,49 & 12,23 & 4,48 & 16,71 & 41,20 & 6,63 & 47,83 & 18,19 & 26,39 \\
\hline 850 & 9,98 & 13,29 & 1,08 & 1,47 & 25,82 & 12,23 & 4,48 & 16,71 & 42,53 & 6,84 & 49,37 & 18,77 & 25,57 \\
\hline 900 & 10,55 & 14,04 & 1,08 & 1,47 & 27,15 & 12,23 & 4,48 & 16,71 & 43,86 & 7,06 & 50,92 & 19,36 & 24,79 \\
\hline 950 & 11,13 & 14,79 & 1,08 & 1,47 & 28,47 & 12,23 & 4,48 & 16,71 & 45,18 & 7,27 & 52,45 & 19,94 & 24,07 \\
\hline 1000 & 11,70 & 15,54 & 1,08 & 1,47 & 29,80 & 12,23 & 4,48 & 16,71 & 46,51 & 7,48 & 53,99 & 20,53 & 23,38 \\
\hline
\end{tabular}

VS - Vlaka i sječina - Felling site

PS - Pomoćno stovarište - Landing

NT - Neopterećeni skider - Unloaded skidder

OT - Opterećeni skider - Loaded skidder

SVv - Zbroj varijabilnih vremena - Sum of variable times

RS - Rad na sječini - Work in felling

RPS - Rad na pomoćnom stovarištu - Work on landing
SUI - Zbroj utovara i istovara - Sum of loading and discharging

EV - Efektivno vrijeme turnusa - Effective time

DV - Dodatno vrijeme (iznosi 32,18 \%) - Allowance time (32.18\%)

UVt - Ukupno vrijeme po turnusu - Cycle time

NV - Norma vremena - Standard time

DU - Dnevni učinak - Daily output 
kretalo od 3,58 minuta za udaljenost od 100 metara do 7,48 minuta za udaljenost od 1000 metara. Ukupno vrijeme turnusa kreće se od 25,86 minuta za udaljenost privlačenja od 100 metara pa do 53,99 minuta na udaljenosti od 1000 metara. Dnevni je učinak bio najveći na udaljenosti od 100 metara i iznosio je $48,83 \mathrm{~m}^{3} /$ dan te je opadao s povećanjem udaljenosti privlačenja pa je na 1000 metara iznosio samo $23,38 \mathrm{~m}^{3} /$ dan.

U tablici 6 prikazan je dnevni učinak i troškovi skidera Timberjack $240 \mathrm{C}$ po jedinici proizvoda (1 $\left.\mathrm{m}^{3}\right)$. Podaci iz tablice pokazuju da je dnevni učinak skidera Timberjack $240 \mathrm{C}$ kod udaljenosti privlačenja od 100 metara $48,83 \mathrm{~m}^{3} /$ dan, što daje trošak od 50,59 $\mathrm{kn} / \mathrm{m}^{3}$. S povećanjem udaljenosti privlačenja učinak skidera opada, a trošak raste, tako da je kod udaljenosti od 1000 metara učinak $23,38 \mathrm{~m}^{3} /$ dan, a trošak $105,64 \mathrm{kn} / \mathrm{m}^{3}$.

Tablica 6. Dnevni učinak i troškovi skidera Timberjack 240C po jedinici proizvoda $\left(1 \mathrm{~m}^{3}\right)$ na radilištu Okučanska brda

Table 6 Daily output and costs of skidder Timberjack 240 C per $\mathrm{m}^{3}$ of timber in management unit Okučanska brda

\begin{tabular}{|c|c|c|c|}
\hline $\begin{array}{l}\text { Udaljenost } \\
\text { Distance }\end{array}$ & $\begin{array}{c}\text { Dnevni učinak } \\
\text { Daily output }\end{array}$ & \multicolumn{2}{|c|}{ Trošak - Cost } \\
\hline $\mathrm{m}$ & $\mathrm{m}^{3} / \mathrm{dan}$ & $\mathrm{kn} / \mathrm{dan}$ & $\mathrm{kn} / \mathrm{m}^{3}$ \\
\hline 100 & 48,83 & 2470 & 50,59 \\
\hline 150 & 45,96 & 2470 & 53,74 \\
\hline 200 & 43,43 & 2470 & 56,88 \\
\hline 250 & 41,18 & 2470 & 59,99 \\
\hline 300 & 39,15 & 2470 & 63,09 \\
\hline 350 & 37,33 & 2470 & 66,17 \\
\hline 400 & 35,67 & 2470 & 69,25 \\
\hline 450 & 34,16 & 2470 & 72,31 \\
\hline 500 & 32,77 & 2470 & 75,37 \\
\hline 550 & 31,50 & 2470 & 78,42 \\
\hline 600 & 30,32 & 2470 & 81,47 \\
\hline 650 & 29,23 & 2470 & 84,50 \\
\hline 700 & 28,22 & 2470 & 87,54 \\
\hline 750 & 27,27 & 2470 & 90,56 \\
\hline 800 & 26,39 & 2470 & 93,59 \\
\hline 850 & 25,57 & 2470 & 96,61 \\
\hline 900 & 24,79 & 2470 & 99,62 \\
\hline 950 & 24,07 & 2470 & 102,63 \\
\hline 1000 & 23,38 & 2470 & 105,64 \\
\hline
\end{tabular}

U tablici 7 prikazan je dnevni učinak i troškovi skidera Timberjack $240 \mathrm{C}$ s dvobubanjskim vitlom Adler HY16 po jedinici proizvoda $\left(1 \mathrm{~m}^{3}\right)$.
Podaci iz tablice govore da je dnevni učinak traktora Timberjack $240 \mathrm{C}$, kod udaljenosti privlačenja od 100 metara, $41,10 \mathrm{~m}^{3} /$ dan, što daje trošak od 60,10 $\mathrm{kn} / \mathrm{m}^{3}$. S povećanjem udaljenosti privlačenja učinak traktora opada, a trošak raste, tako da je kod udaljenosti od 1000 metara učinak $23,84 \mathrm{~m}^{3} /$ dan, a trošak od $103,62 \mathrm{kn} / \mathrm{m}^{3}$.

Tablica 7. Dnevni učinak i troškovi skidera Timberjack $240 \mathrm{C}$ po jedinici proizvoda $\left(1 \mathrm{~m}^{3}\right)$ na radilištu Južni Psunj

Table 7 Daily output and costs of skidder Timberjack $240 \mathrm{C}$ per $m^{3}$ of timber in management unit Južni Psunj

\begin{tabular}{|c|c|c|c|}
\hline $\begin{array}{c}\text { Udaljenost } \\
\text { Distance }\end{array}$ & $\begin{array}{c}\text { Dnevni učinak } \\
\text { Daily output }\end{array}$ & \multicolumn{2}{|c|}{ Trošak-Cost } \\
\hline $\mathrm{m}$ & $\mathrm{m}^{3} / \mathrm{dan}$ & $\mathrm{kn} / \mathrm{dan}$ & $\mathrm{kn} / \mathrm{m}^{3}$ \\
\hline 100 & 41,10 & 2470 & 60,10 \\
\hline 150 & 38,29 & 2470 & 64,51 \\
\hline 200 & 36,19 & 2470 & 68,26 \\
\hline 250 & 34,51 & 2470 & 71,58 \\
\hline 300 & 33,11 & 2470 & 74,59 \\
\hline 350 & 31,92 & 2470 & 77,37 \\
\hline 400 & 30,89 & 2470 & 79,97 \\
\hline 450 & 29,97 & 2470 & 82,42 \\
\hline 500 & 29,15 & 2470 & 84,73 \\
\hline 550 & 28,41 & 2470 & 86,95 \\
\hline 600 & 27,73 & 2470 & 89,06 \\
\hline 650 & 27,11 & 2470 & 91,09 \\
\hline 700 & 26,54 & 2470 & 93,05 \\
\hline 750 & 26,01 & 2470 & 94,95 \\
\hline 800 & 25,52 & 2470 & 96,78 \\
\hline 850 & 25,06 & 2470 & 98,56 \\
\hline 900 & 24,63 & 2470 & 100,29 \\
\hline 950 & 24,22 & 2470 & 101,98 \\
\hline 1000 & 23,84 & 2470 & 103,62 \\
\hline
\end{tabular}

Iz tablice 7 vidimo da je dnevni učinak traktora Timberjack $240 \mathrm{C}$ na radilištu Južni Psunj kod udaljenosti privlačenja 100 metara najveći, a za udaljenost privlačenja od 1000 metara najmanji. Vidimo i da su dnevni učinak skidera i trošak po jedinici proizvoda obrnuto proporcionalni.

\section{Zaključci - Conclusions}

$\mathrm{U}$ radu je istraživan učinak zglobnoga skidera Timberjack 240 C pri privlačenju drvnih sortimenata u dovršnoj i naplodnoj sječi. Terenska su istraživanja provedena na području Šumarije Okučani u odjelu 44a GJ Okučanska brda i na području Šuma- 
rije Nova Gradiška, odjel 74a GJ Južni Psunj. Tlo je tijekom istraživanja bilo vlažno do blatno, na dijelovima teško prohodno.

Na radilištima su radili traktorist i pomoćni radnik na vezanju tovara. Sječa i izrada obavljena je prije privlačenja drvnih sortimenata, a preuzimanje drvnih sortimenata odvijalo se u sječini pored panja te povremeno na pomoćnom stovarištu.

Na temelju oblikovane norme dnevnoga učinka i kalkulacije troškova izračunati su troškovi privlačenja drva za udaljenost od $100 \mathrm{~m}$ do $1000 \mathrm{~m}$, koji se kreću od $50,59 \mathrm{kn} / \mathrm{m}^{3}$ do $105,64 \mathrm{kn} / \mathrm{m}^{3}$ u odjelu $44 \mathrm{a}$ i od $60,10 \mathrm{kn} / \mathrm{m}^{3}$ do $103,62 \mathrm{kn} / \mathrm{m}^{3}$ u odjelu 74a. Prema prosječno ostvarenim uvjetima radilišta moguće je značajno povećati učinak i smanjiti trošak boljim korištenjem radnoga vremena.

Prema Krpanu i Zečiću (2001) skideri iz obitelji Timberjack imaju prosječni obujam tovara od 4,02 $\mathrm{m}^{3}$ pa do $6,31 \mathrm{~m}^{3}$, a prema Zečiću i dr. (2010) pri privlačenju drvnih sortimenata u prebornim šumama prosječni je obujam tovara $5,04 \mathrm{~m}^{3}$. Iz istraživanja se vidi kako se većim obujmom tovara značajno povećava proizvodnost toga traktora, a time se smanjuju troškovi po jedinici proizvoda. Traktor Timberjack 240C pripada skupini visoko učinkovitih specijalnih šumskih strojeva za privlačenje drva po tlu, a posebno u oplodnim sječama primjenom poludeblovne ili deblovne metode. Za njegovu je primjenu potrebno prethodno izraditi elaborat radilišta sa svim utjecajnim čimbenicima te neprestano nadzirati tijek rada. Mjerenjima u ovom radu dobiven je prosječni obujam tovara od 2,63 $\mathrm{m}^{3}$ na jednom radilištu i 3,26 $\mathrm{m}^{3}$ na drugom radilištu, što potvrđuje činjenicu da se kod sortimentne metode privlačenja postižu značajno manji učinci zbog prosječno manjega obujma tovara u odnosu na primjenu poludeblovne ili deblovne metode kod kojih je prosječni obujam tovara mnogo veći.

\section{Literatura - References}

Bojanin, S., 1971: Analiza rada zglobnih traktora kod izvlačenja debala. Šumarski list 96(7-8): 231-255.

Bojanin, S., 1980: Problemi klasifikacije šumskih terena. Mehanizacija šumarstva 5(5-6): 176-187.

Bojanin, S., 1983: Faktori optimalne otvorenosti šuma kod sekundarnog otvaranja. Mehanizacija šumarstva 8 (1112): 322-325.

Bojanin, S., A.P.B., Krpan, 1997: Mogućnost tzv. visokog i potpunog mehaniziranja sječe i izrade te mehaniziranja privlačenja drva u šumama Hrvatske. Šumarski list 121(78): 371-381.
Horvat, D., Ž. Zečić, M. Šušnjar, 2007: Morphological characteristics and productivity of skidder Ecotrac 120V. Croatian Journal of Forest Engineering 26(1): 13-27.

Krivec, A., 1979: Učinkovitost in oblikovanje novih organizacijskih postopkov pri spravljanju lesa s traktorji Neue Formen. Gazdarski vestnik 37(7-8): 305-360.

Krpan, A. P. B., 1990: Prilog klasifikaciji šumskih terena u svjetlu eksploatacije šuma u teškim uvjetima. Mehanizacija šumarstva 15(5-6): 107-110.

Krpan, A.P.B., 1992: Iskorišćivanje šuma. U: Šume u Hrvatskoj, Đ. Rauš (ur.), Šumarski fakultet Sveučilišta u Zagrebu i J. P. »Hrvatske šume«, Zagreb, 153-170.

Krpan, A.P.B., Ž. Zečić, 2001: Učinkovitost i troškovi traktora Timberjack $240 \mathrm{C}$ pri privlačenju drva u brdskim oplodnim sječama. U: Znanost u potrajnom gospodarenju hrvatskim šumama, S. Matić, A.P.B. Krpan, J. Gračan (ur.), Šumarski fakultet Zagreb - Šumarski institut Jastrebarsko, 477-490.

Martinić, I., 1990: Interakcije metoda rada, radnih uvjeta i proizvodnosti rada pri sječi i izradi drva u proredama sastojina. Magistarski rad, Šumarski fakultet Sveučilišta u Zagrebu, 1-100.

Martinić, I., 1995: Ekonomski i organizacijski kriteriji za oblikovanje šumskih radova. Disertacija, Šumarski fakultet Sveučilišta u Zagrebu, Zagreb, 1-202.

Matić, S., 1983: Šuma i mehanizacija. Zbornik savjetovanja „Šumarska mehanizacija u teoriji i praksi«, Opatija, 37-46.

Pečnjak, D., 2011: Učinkovitost traktora Timberjack 240 C pri privlačenju drva u brdskim uvjetima primjenom sortimentne metode. Magistarski rad, Šumarski fakultet Sveučilišta u Zagrebu, 1-99.

Sabo, A., 1999: Privlačenje oblog drva zglobnim traktorom LKT 81 u gorskokotarskim prebornim sastojinama različitog stupnja otvorenosti. Magistarski rad, Šumarski fakultet Sveučilišta u Zagrebu, 1-142.

Taboršak, D., 1987: Studij rada. Tehnička knjiga, Zagreb, 1-214.

Vila, A., 1962: Priprema rada. Privreda, Zagreb, 149 str.

Zečić, Ž., A.P.B. Krpan, B. Stankić, 2004: Privlačenje oblovine traktorom Timberjack $240 \mathrm{C}$ iz oplodne sječe u uvjetima Šumarije Velika Pisanica. Šumarski list 128(11-12): 671-678.

Zečić, Ž., D. Vusić, M. Prka, S. Klepac, 2010: Utjecaj nagiba traktorskog puta na proizvodnost traktora Timberjack 240C pri privlačenju drvnih sortimenata u prebornim šumama. Šumarski list 134(3-4): 103-114.

Zečić, Ž., D. Vusić, H. Nevečerel, M. Mikulin, 2011: Utjecaj obujma tovara na proizvodnost traktora Timberjack 240C pri privlačenju debala euroameričke topole $u$ nizinskim šumama. Croatian Journal of Forest Engineering 32(1): 357-368. 


\section{Abstract}

\section{Efficiency of Cable Skidder Timberjack 240 C in Timber Extraction Using the Assortiment Method}

This paper examines the effect of Timberjack $240 \mathrm{C}$ in timber extraction in the final and seeding felling. Field surveys were conducted in the area of Okučani Forest Office, compartmet 44 a of the Management Unit »Okučanska brda " and in the area of Nova Gradiška Forest Office, compartment 74a of the Management Unit »Južni Psunj«. For Timberjack 240 $C$ in the compartment 44a, during 11 days, 4406.12 minutes were recorded at the work site, which is 400.56 minutes per day, or $83.45 \%$ of the prescribed working time of 480 minutes. Of the total recorded time, the effective time is 3300.02 minutes or $74.90 \%$, while the general time is 1106.10 minutes or $25.10 \%$. For Timberjack $240 \mathrm{C}$ in the compartment $74 a, 2641.57$ minutes were recorded during 9 days at the work site, which is 293.51 minutes per day, or $61.15 \%$ of the prescribed working time of 480 minutes. Of the total recorded time, the effective time is 2157.20 minutes or $81.66 \%$, while the general time is 484.37 minutes or $18.34 \%$. Allowance time is $16.09 \%$ and $20.37 \%$ of the effective time. Skidder Timberjack $240 \mathrm{C}$ is one of the most efficient machines for timber extraction, and especially for final felling, when using the half-trunk and trunk method. For the application of such skidder, it is necessary to prepare the study site with all the influencing factors and constantly monitor the workflow. In skidding wood assortments, significantly smaller effects are achieved due to a smaller load volume.

Keywords: cable skidder Timberjack 240 C, timber extraction, productivity, costs

Primljeno (Received): 19. 10. 2019.

Prihvaćeno (Accepted): 27. 11. 2019.

Adrese autorâ - Authors' addreses:

Prof. dr. sc. Željko Zečić

e-pošta: zecic@sumfak.hr

Prof. dr. sc. Ivan Martinić

e-pošta: imartinic@sumfak.hr

Doc. dr. sc. Dinko Vusić

e-pošta:dvusic@sumfak.hr

Doc. dr. sc. Matija Landekić

e-pošta: mlandekic@sumfak.hr

Dr. sc. Matija Bakarić*

e-pošta: mbakaric@sumfak.hr

Šumarski fakultet Sveučilišta u Zagrebu

Zavod za šumarske tehnike i tehnologije

Svetošimunska 25

10000 Zagreb

HRVATSKA

Mr. sc. Davorin Pečnjak, dipl. ing. šum.

e-pošta: davorin.pecnjak@hrsume.hr

Frankopanska 37

35400 Nova Gradiška

HRVATSKA

${ }^{*}$ Glavni autor - Corresponding author 
